DOI: 10.17951/lrp.2019.38.4.143-154

\author{
JOANNA WRÓTNIAK \\ Uniwersytet Marii Curie-Skłodowskiej \\ Wydział Pedagogiki i Psychologii \\ ORCID - 0000-0002-0492-4396
}

\title{
TRUDNOŚCI UCZNIA NIEŚMIAŁEGO
}

Streszczenie: Niniejsze opracowanie jest poświęcone problematyce nieśmiałości wśród uczniów. Problem nieśmiałości i konsekwencje, jakie za sobą niesie, są w dużej mierze bagatelizowane przez środowisko szkolne i pomijane przez nauczycieli. W artykule skoncentrowano się na ukazaniu nieśmiałości w kategorii jednego z przejawów trudności wychowawczych. Zdefiniowano pojęcie nieśmiałość i zwrócono uwagę na specyfikę tego zjawiska oraz problemy, z jakimi borykają się uczniowie nieśmiali. Uczeń nieśmiały określany jest jako grzeczny, taktowny, a nawet godny naśladowania, tymczasem nieśmiałość może mieć bardzo niekorzystny wpływ na życie młodego człowieka. Konieczne jest zatem uwrażliwienie nauczycieli i wychowawców na potrzeby ucznia nieśmiałego i konieczność podjęcia wobec niego specjalnych oddziaływań wychowawczych.

Słowa kluczowe: trudności wychowawcze, trudny uczeń, nieśmiałość, uczeń nieśmiały

Życie człowieka nieśmiałego, w tym również nieśmiałego ucznia w szkole, składa się z wielu zmarnowanych szkolnych okazji

Christoph Andre

\section{WPROWADZENIE}

Problem nieśmiałości wydaje się pomijany w szerokiej dyskusji dotyczącej problematyki wychowania, przede wszystkim ze względu na brak niedogodności dla otoczenia. Bowiem uczeń nieśmiały jest „wygodniejszy” w wychowaniu - spokojny, uległy, niezadający kłopotliwych pytań nauczycielowi. Tym samym dość często 
niezauważany i niepostrzegany przez nauczyciela jako uczeń problemowy. W środowisku szkolnym obok uczniów, którzy z łatwością nawiązują kontakty, spotykamy również tych, dla których funkcjonowanie w grupie jest dużym problemem. Analiza funkcjonowania dzieci nieśmiałych oraz przyczyn tego zjawiska ujawnia wiele czynników świadczących o niekorzystnym przebiegu procesu rozwoju oraz akcentuje konieczność podejmowania działań o charakterze wychowawczym i profilaktycznym.

\section{OGÓLNA CHARAKTERYSTYKA NIEŚMIAŁOŚCI}

Zainteresowanie nieśmiałością sięga 1901 roku, kiedy Paul Hartenberg (za: Harwas-Napierała 1995) zdefiniował ją jako „[...] skłonność do odczuwania niepokoju w warunkach charakteryzujących się obecnością innych osób” (za: Januszewska 2000), mimo to nieśmiałość nadal nie posiada jednolitej definicji.

Nieśmiałość jest zjawiskiem powszechnym, dotyka dzieci, młodzież, osoby dorosłe. Według Philipa G. Zimbardo (2007) aż 80\% osób doświadcza nieśmiałości w pewnych okolicznościach życia, z czego $12 \%$ odczuwa nieśmiałość każdego dnia, a 2\% uważa się za „chronicznie nieśmiałych”. Zdaniem autora społeczeństwo o cechach indywidualistycznych i rywalizacyjnych nie ułatwia nabywania umiejętności społecznych, a tym samym sprzyja wzrostowi nieśmiałości.

Według Słownika Współczesnego Języka Polskiego (1998, s. 607) nieśmiałość to „brak pewności siebie, śmiałości, wstydliwość, lękliwość”.

Ludovic Dugas (za: Januszewska 2000) twierdzi, że nieśmiałość oznacza z jednej strony przejściowy niepokój i zakłócenie osobowości lub niepokój stale odnawiany, który potęguje się za każdym razem, a z czasem przeradza się w stałą postawę. Nieśmiałość w niektórych przypadkach jest też powodem zakłóceń w funkcjonowaniu człowieka, kiedy jego aktywność odbywa się w obecności innych osób. Zakłócenia tej aktywności, które wynikają z koncentrowania się osób nieśmiałych na wewnętrznym przymusie zwracania uwagi na osoby będące świadkami danej aktywności, zmniejszają ogólną skuteczność działania, a w konsekwencji mogą być nawet źródłem nieprzyjemności i cierpień.

Nieśmiałość to zarówno lekkie uczucie skrępowania, niczym nieuzasadniony lęk przed ludźmi, jak i ostry zespół reakcji nerwicowych (Jagieła 2005).

Hanna Hamer (za: Gromelska 2009, s. 19) uważa, że „nieśmiałość przypomina psychiczny paraliż. Jest rodzajem postawy składającej się z zespołu przykrych uczuć, obezwładniających myśli na swój temat i gotowości do wycofania się z trudnych sytuacji. [...] W zależności od sytuacji może przybierać różne natężenia, np. od lekkiego skrępowania, przez lęk bez wyraźnego powodu, aż do paniki i chęci natychmiastowej ucieczki". 
Barbara Harwas-Napierała (1995) wyjaśnia, że u podstaw nieśmiałości leży swoisty obraz własnej osoby powodujący spostrzeganie negatywnej rozbieżności między własnym, rzeczywistym a akceptowanym (wyobrażonym) spełnianiem standardów (zadań i wymagań) społecznych, przyczyn tego nastawienia zaś należałoby szukać, ustalając warunki, które mogły doprowadzić do pojawienia się wspomnianej rozbieżności. Zdaniem autorki nieśmiałość przejawia się w formie trzech podstawowych komponentów: zahamowania, bierności i wycofywania. Zahamowanie jest rozumiane jako zablokowanie zwykłych form reagowania w sytuacji oceny i ekspozycji społecznej, któremu towarzyszą objawy fizjologiczne, lęk, poczucie „pustki w głowie” oraz niezgrabności i dyskomfortu. Bierność przejawia się w powstrzymywaniu się od działania, unikaniu aktywności w grupie, braku inicjatywy. Wycofywanie dotyczy rezygnowania z kontaktów międzyludzkich, któremu towarzyszy poczucie niższej wartości, oczekiwanie porażki.

W literaturze przedmiotu dominuje ujęcie syndromalne nieśmiałości wskazujące na aspekt behawioralny, emocjonalny i samoorientacyjny tego zjawiska. Ujęcie syndromalne wiąże nieśmiałość na ogół z doznawaniem dyskomfortu psychicznego, spowodowanego przede wszystkim odczuwaniem lęku w sytuacjach różnego typu interakcji społecznych i negatywną samooceną, jak również $\mathrm{z}$ dezorganizacją działania $\mathrm{w}$ tych sytuacjach.

Współcześnie nieśmiałość określana jest jako: „[...] złożony zespół objawów, wiążący się z zaburzeniami w zakresie sfery behawioralnej, emocjonalnej i samoorientacyjnej" (Zabłocka 2012, s. 15; por Harwas-Napierała 1995, s. 20). Zaburzenia w sferze behawioralnej polegają na zahamowaniu aktywności jednostki w sytuacji społecznej ekspozycji. Zaburzenia w sferze emocjonalnej obejmują następujące obszary: obawę przed negatywną oceną ze strony innych, uczucie zażenowania w sytuacjach społecznych, doświadczanie lęku, pojawiającego się, gdy nieśmiali obawiają się tego, że są oceniani, poczucie osobistego zagrożenia w sytuacjach kontaktu społecznego oraz strach przed kontaktami z innymi osobami. Zaburzenia w sferze samoorientacji obejmują przede wszystkim skłonność do marzycielstwa, zakłócenie procesów myślenia, poczucie niższości i brak wiary w siebie. Osobom nieśmiałym nieustannie towarzyszy obawa przed kompromitacją, krytyką, wyśmianiem, doznaniem porażki i przykrości (Zabłocka 2012; Harwas-Napierała 1995; Leary 2001).

Zdaniem Małgorzaty Zabłockiej (2012) dla zrozumienia specyfiki nieśmiałości dziecka uzasadnione jest rozpoczęcie od sfery samoorientacyjnej, poprzez emocjonalną, do behawioralnej. Bowiem to, jak dziecko myśli o sobie (sfera samoorientacyjna) ma znaczenie dla odczuwanych w sytuacjach społecznych emocji (sfera emocjonalna), a te z kolei mogą motywować do ucieczki z tego typu sytuacji (sfera behawioralna). 
Nieśmiałość jest pojęciem nieostrym. Głębsze analizy tego zjawiska ujawniają wiele odmian nieśmiałości, co pozwala ją traktować jako przypadłość, która pociąga za sobą całą gamę skutków - od lekkiego uczucia skrępowania, nieuzasadnionego lęku przed ludźmi, aż do skrajnej nerwicy (Zimbardo 2007, s. 21-22).

Można zatem wyróżnić nieśmiałość:

1. Chwilową przeżywaną jako stan w pewnego typu sytuacjach społecznych (onieśmielenie).

2. Przejściową związaną z dynamiką rozwoju psychicznego, a zwłaszcza formowaniem się osobowości. Najczęściej występuje u dzieci i młodzieży, jest przejawem kryzysowych momentów w procesie kształtowania się osobowości.

3. Trwałą, charakteryzującą pewnych ludzi przez całe życie w skutek określonego ukształtowania ich osobowości (Głuszak 2012).

Ze względu na psychospołeczne skutki nieśmiałości bardzo istotna jest jej etiologia. Psychologowie społeczni postulują, że początkiem nieśmiałości jest tzw. etykieta „nieśmiały” - jestem nieśmiałym, bo tak o sobie mówię lub inni tak mnie nazywają. Badacze osobowości twierdzą, że nieśmiałość jest cechą dziedziczną, podobnie jak inteligencja czy wzrost. Behawioryści są zdania, że osoby nieśmiałe nie przyswoiły sobie umiejętności społecznych niezbędnych w relacjach z innymi ludźmi. Psychoanalitycy uważają zaś, że zjawisko to jest symptomem, uświadomionym przejawem nieuświadomionych konfliktów w psychice. Istotny wpływ na kształtowanie się nieśmiałości u dziecka ma typ układu nerwowego - jego temperament. Nieśmiałości mogą sprzyjać takie cechy temperamentu, jak: uczuciowość, wrażliwość, skłonność do zamykania się w sobie (Gromelska 2009).

W genezie nieśmiałości, obok zmiennych osobowościowych, dominującą rolę odgrywają uwarunkowania środowiskowe. Pierwszym, podstawowym środowiskiem jest rodzina, w której poprzez modelowanie uczymy się zachowań. Badania świadczą, że na pojawienie się u dziecka predyspozycji do zachowań nieśmiałych ma wpływ nastawienie rodzica do swojego dziecka. Badania prowadzone przez Barbarę Harwas-Napierałę (1995) wykazują, że rodzice dzieci nieśmiałych są bardziej surowi, skłonni do gniewu, unikają rozmów z dziećmi. Badania Danuty Boreckiej-Biernat (1998) dowodzą, że odrzucenie emocjonalne, zaniedbujący styl wychowania, brak kontaktu rodzica z dzieckiem są predykatorami pojawienia się opisywanej cechy. Dziecko rodziców nadmiernie wymagających stanie się niepewne, ponieważ nie może im sprostać, czuje się gorsze, słabsze i ma zaniżoną samoocenę. Na drugiej skrajności stoją rodzice reprezentujący postawę nadmiernie chroniącą, która może przyjąć dwojaką formę, tj. nadmiernej opieki pobłażliwej i opieki opartej na dominacji. Rodzice nadopiekuńczy spełniają każde życzenie dziecka. Ograniczają w ten sposób 
jego samodzielność, uniemożliwiając mu naukę na własnych błędach. Nadmierna opiekuńczość rodziców powoduje, że dziecko traci swoją wolność i niezależność, nie jest zaspokajana potrzeba niezależności i autonomii, co może i prowadzi do powstania lęku i niepokoju. W sytuacji zagrożenia takie dziecko wycofa się z obawy przed porażką (Harwas-Napierała 1995). W zależności od poziomu wymagań dziecko jest zachęcane do zdobywania nowych doświadczeń lub nadmiernie ochraniane i wzmacniane w postawach zależnościowych (por. Harwas-Napierała 1979; Gromelska 2009).

Zdaniem Barbary Harwas-Napierały (1995, s. 32) istnieją podstawy, by mówić, że „nieśmiałość może być w niektórych przypadkach wyuczoną formą zachowania, na skutek obserwacji i częstszego kontaktu z osobami przejawiającymi takie właśnie zachowanie, tj. jako rezultat oddziaływania modeli, najczęściej rodziców”. Innym powodem kształtowania się nieśmiałości, zdaniem autorki „[... jest deprywacja określonych potrzeb dziecka m.in.: potrzeby bezpieczeństwa, samodzielności, niezależności. Nie zaspokojenie tych potrzeb uwarunkowane jest głównie postawą nadmiernego ochraniania bądź postawą nadmiernych wymagań, szczególnie ze strony matek".

Drugim środowiskiem obok rodziny jest szkoła, która wciąż w zbyt dużym stopniu skupia się na krytykowaniu i wytykaniu różnych błędów uczniom, co może być szczególnie dotkliwe dla uczniów nieśmiałych. Środowisko szkolne przyczynia się niejednokrotnie do nasilenia problemów, jakie stwarza uczniom nieśmiałość. Błędy wychowawcze popełniane przez nauczycieli, w postaci rygoryzmu, publicznego egzekwowania wiedzy i umiejętności, stosowania wzmocnień negatywnych za nienależyte wywiązanie się z poleceń i obowiązków, mogą pogłębiać nieśmiałość ucznia. Dziecko pod wpływem rygoryzmu nauczyciela staje się bierne, podporządkowane, mało spontaniczne, nie potrafi samodzielnie działać, jego aktywność twórcza jest znacznie ograniczona, ma poczucie, że nie potrafi niczego dobrze wykonać, dlatego ma niską samoocenę. Rygoryzm wyzwala lęk i opór (Gurycka 1990). Nieśmiałe dzieci są posłuszne, rzadko sprawiają kłopoty, dlatego nauczyciele poświęcają im mniej swojej uwagi. Sporadycznie powierzają im odpowiedzialne funkcje (Głuszak 2012).

Zdaniem Zimbardo (2007, s. 20) skutki nieśmiałości mogą wpływać niszcząco na jednostkę, przede wszystkim dlatego, że nieśmiałość:

- utrudnia poznawanie nowych osób i nawiązywanie przyjaźni oraz odbiera radość płynącą z pozytywnych przeżyć wywołanych kontaktami społecznymi;

- utrudnia przejawianie asertywności m.in. w zakresie publicznej obrony własnych poglądów i praw oraz wyrażania swoich opinii i prezentowania własnych wartości; 
- uniemożliwia pełną autoprezentację poprzez nieujawnianie mocnych stron;

- przyczynia się do zakłopotania i zbytniej koncentracji na swoich własnych reakcjach;

- utrudnia precyzyjne myślenie i skuteczne porozumiewanie się z innymi ludźmi;

- niejednokrotnie współwystępuje z takimi ujemnymi stanami, jak depresja, lęk czy samotność.

Potwierdzeniem powyższych ustaleń są prowadzone w tym zakresie badania empiryczne. Z badań Danuty Boreckiej-Biernat (2000) dotyczących związku nieśmiałości z samooceną młodzieży wynika, że osoby nieśmiałe odznaczają się zarówno niskim poziomem samooceny ogólnej, jak i poszczególnych jej elementów, tj. dotyczących niezadowolenia z siebie, niskiego oceniania siebie $\mathrm{w}$ zakresie pełnionych ról społecznych zarówno w środowisku rodzinnym, jak i i społecznym. Badania Ireny Dzwonkowskiej (2003) wykazały korelację między nieśmiałością a wsparciem społecznym, negatywnymi stosunkami z bliskimi, depresją, samotnością, poczuciem własnej wartości. Wyniki badań uwidoczniły, że im bardziej osoba jest nieśmiała, tym ma mniej bliskich relacji z bliskimi, odczuwa mniej wsparcia ze strony rodziny, bliskich, co zwiększa u niej depresje. Nieśmiali respondenci odznaczali się wyższą samotnością, częstszym doświadczaniem negatywnych stanów emocjonalnych, niższym poczuciem własnej wartości, mniejszą towarzyskością oraz mniejszym waloryzowaniem siebie jako partnera w towarzystwie. Badania Magdaleny Umeckiej (2008, s. 26) wskazują na stosowanie przez osoby nieśmiałe niekonstruktywnych sposobów i strategii radzenia sobie ze stresem. Z badań wynika, że młodzież nieśmiała unika trudnych sytuacji, kontaktów z innymi, obsesyjnie myśli o zaistniałej trudnej sytuacji i nie potrafi skoncentrować się na czymś innym. Doświadcza przy tym poczucia przygnębienia i beznadziejności, choć pozornie godzi się z porażką. Elżbieta Januszewska (2000) w swoich badaniach wykazała różnice osobowościowe między dziećmi śmiałymi i nieśmiałymi. Dzieci nieśmiałe są introwertywne, mają mniejszą potrzebę kontaktu z innymi, z rezerwą okazują uczucia i emocje, poszukują samotności, są bardzo wrażliwe na niebezpieczeństwa. Dzieci te są bardziej przygnębione, zamknięte w sobie, apatyczne, skryte. Nie zabiegają o swoją rolę czy miejsce w grupie. Nie odczuwają potrzeby społecznego angażowania się w działanie. W relacji są raczej uległe, mają tendencje do obwiniania siebie i stawiania zbyt wysokich wymagań. Kierują agresję do wewnątrz, co sprzyja napięciu nerwowemu i trudności w jego rozładowaniu. 


\section{DZIECKO NIEŚMIAŁE JAKO UCZEŃ SPRAWIAJĄCY TRUDNOŚCI WYCHOWAWCZE}

Dziecko nieśmiałe w szkole zaliczane jest do grupy uczniów sprawiających trudności wychowawcze (zob. Łobocki 1989; Bandura 1958). Trudności wychowawcze określane są najczęściej w literaturze jako wszelkie postępowania wychowanka niezgodne z celami wychowania, które nie odpowiadają oczekiwaniom otaczającego go społeczeństwa. Tkwią w dziecku. Są to pewne cechy zachowania, które stwarzają komplikacje, zależą one od wieku, w jakim jest wychowanek i są jedną z przeszkód w nauczaniu i wychowaniu. Nie poddają się zwykłym zabiegom wychowawczym i wynikają one z pojawiających się przeszkód oraz niepowodzeń występujących w środowisku rodzinnym i szkolnym (por. Rogers 2011; Dąbrowska, Wojciechowska-Charlak 2005; Łobocki 1989).

Dziecko trudne to takie, z którego wychowaniem i socjalizacją wiążą się zróżnicowane problemy i bariery rozwojowe, tj. dziecko rozbiegane, krnąbrne, złośliwe lub apatyczne, unikające kontaktu z innymi osobami, izolujące się, nieprzewidywalne w swoim zachowaniu, przekraczające granice, czyli odstające od powszechnie przyjmowanych standardów (Kowolik 2013). Trudny uczeń jest wyzwaniem dla kompetencji nauczycielskich i wychowawczych. Zdaniem Jarosława Jagieły (2005, s. 13-14) „uczeń trudny w prezentowanym przez siebie zachowaniu w sposób celowy i zamierzony, lub w nie do końca sobie uświadamiany, stara się bojkotować czy w inny sposób unieważniać wysiłki wychowawcze i dydaktyczne rodziców, szkoły i nauczycieli". Wielość zachowań ucznia sprawiającego problemy wychowawcze obejmuje listę symptomów charakterystyczną dla wielu różnych, wzajemnie wykluczających się stanów osobowości.

Ludwik Bandura wyodrębnia dwie grupy dzieci i wskazuje na przejawiane przez nich określone problemy wychowawcze. Do pierwszej grupy zalicza „trudności wychowawcze spowodowane przez dzieci o przewadze procesów pobudzania”. Do tej grupy należą dzieci agresywne, nadpobudliwe, aroganckie, zuchwałe. Naruszają one dyscyplinę szkolną poprzez wyzywające zachowanie, brak obowiązkowości, lekceważący stosunek do szkoły i nauczyciela, ucieczki, kradzieże. W drugiej grupie zamieszcza „trudności wychowawcze spowodowane przez dzieci o przewadze procesów hamowania". W tej grupie znajdują się dzieci nieśmiałe, apatyczne, nieufne, bez wiary w siebie, sprawiające wrażenie dzieci o niepełnosprawności intelektualnej, unikające towarzystwa, mało aktywne (Dąbrowska, Wojciechowska-Charlak 2005).

Mieczysław Łobocki dzieli uczniów sprawiających trudności wychowawcze na: przesadnie biernych i nadmiernie aktywnych. Dzieci nadmiernie aktywne poznaje się po szybkich nieskoordynowanych ruchach, obgryzaniu ołówka 
i paznokci, natręctwie i trikach, nerwowym zaburzeniu w sferze uwagi, pamięci i mowy, wzmożonej wrażliwości, lękliwości, agresji słownej i fizycznej. Dzieci przesadnie bierne charakteryzują się natomiast lękliwością, przybierającą niekiedy postać fobii szkolnych, nieśmiałością, ograniczoną aktywnością, brakiem samodzielności, poczuciem osamotnienia, brakiem zainteresowań (Dąbrowska, Wojciechowska-Charlak 2005).

Ucznia nieśmiałego cechuje nadmierna samokontrola, brak zaufania i wiary w siebie, lęk przed odrzuceniem i ciągłe przekonanie, że jest oceniany lub krytykowany. Ma trudności w publicznym wyrażaniu swojego zdania, nazbyt przejmuje się swoimi reakcjami oraz ma problemy z wysławianiem się. Uczeń nieśmiały przegrywa wiele okazji na sukces czy też udaną przyjaźń. Nadmierne onieśmielenie często skazuje ucznia na marginalizację w stosunku do swoich bardziej wygadanych i odważnych kolegów. Ponadto jego wysiłki są często niezauważane i niedoceniane przez nauczycieli, wychowawców (Jagieła 2005).

Uczniowie dotknięci nieśmiałością w klasie szkolnej najczęściej nie podejmują żadnych zadań z własnej inicjatywy, nie biorą aktywnego udziału w lekcjach, nie uczestniczą też w różnego rodzaju imprezach organizowanych przez szkołę. Uczniowie nieśmiali mają trudność z przekazaniem wyuczonego materiału przed klasą i nauczycielem. Mają cichy sposób mówienia, unikają kontaktu wzrokowego. Uczniowie nieśmiali siedzą cicho, nie hałasują, nie wchodzą w kontakt z nauczycielem, pozostają często na uboczu. W obawie przez niekorzystną opinią dzieci stronią od kolegów, przyjmują często tylko rolę obserwatora. W sytuacjach konfliktowych nie bronią swego stanowiska (Głuszak 2012; Zabłocka 2012; por Harwas-Napierała 1995).

Dla nauczyciela nieśmiały wychowanek jest mało kłopotliwy, jednak nie można zapominać, że uczeń nieśmiały choć z pozoru poukładany, siedzący z boku, małomówny, cichy, może być „cykającą bombą”. Z bycia nieśmiałym uczeń może czerpać ukryte gratyfikacje. Spostrzegany jest często przez rówieśników, nauczycieli jako nadmiernie wrażliwy, delikatny i bezkonfliktowy - to tzw. wtórne korzyści z bycia nieśmiałym (Jagieła 2005, s. 49-51).

Uczeń nieśmiały w klasie szkolnej wymaga dodatkowej pomocy i wsparcia ze strony nauczyciela, wychowawcy. Pomimo że jest postrzegany jako cichy, spokojny, niesprawiający problemów wychowawczych, to bezdyskusyjnie należy do grupy uczniów o specjalnych potrzebach wychowawczych. Nieśmiałość bowiem może odcisnąć swoje piętno na całym życiu dziecka, odebrać mu szansę na przeżycie wielu interesujących i przydatnych doświadczeń. Istotne jest tym samym podjęcie przez szkolę działań na rzecz uczniów nieśmiałych, które cechowałby takt pedagogiczny, dyskrecja oraz pełna akceptacja osoby dziecka nieśmiałego. Wskazane jest podjęcie owych działań w atmosferze życzliwości, zrozumienia w relacji nauczyciel - uczeń oraz uczeń - uczeń (Paszkowska, Łobacz 2013, s. 190). 
Oprócz trudności, z jakimi borykają się osoby nieśmiałe, odznaczają się one wieloma pozytywnymi cechami, mają swoje zainteresowania i pasje. Osoby nieśmiałe są bardziej wrażliwe w kontaktach międzyludzkich - rzadziej ranią innych, popełniają mniej gaf, bo bardzo liczą się z innymi ludźmi. Potrafią słuchać, bo nie lubią mówić o sobie. Mają duże zdolności wspierające i są cenieni jako oddani przyjaciele (mają niewielu przyjaciół, ale bardzo bliskich, dla których są w stanie się poświęcać) (Zabłocka 2012).

\section{WSKAZÓWKI DLA NAUCZYCIELI}

$\mathrm{W}$ postępowaniu z uczniem nieśmiałym nauczyciel terapeuta winien wykazać delikatność i zrozumienie specyfiki trudności, powinien stwarzać poczucie bezpieczeństwa i udzielać pomocy w przezwyciężaniu poczucia społecznego zagrożenia i przywracaniu uczniowi wiary we własne siły, możliwości i zdolności. Podjęcie próby przezwyciężania nieśmiałości u dzieci polega na takim pokierowaniu nimi, by stwarzać im z jednej strony okazje do częstego występowania wobec innych ludzi i w ten sposób przyzwyczajać je do tego typu sytuacji, z drugiej natomiast, tak tworzyć sytuacje, by dawać dzieciom możliwość realnego przeżycia sukcesu. W ten sposób można wyprzeć ich negatywną opinię o własnym funkcjonowaniu - przeświadczenie o niemożności sprostania standardom społecznym (Harwas-Napierała 1979, s. 108).

Niewłaściwym sposobem pomocy uczniowi nieśmiałemu jest ośmielanie go na siłę czy też dawanie mu taryfy ulgowej. Wzmacnia to jedynie tego rodzaju zachowania, natomiast nie uczy przezwyciężania lęku. Istotne jest, by uczyć wychowanków koncentrowania się na swoich mocnych stronach i zadaniu. Należy pomagać uczniowi zrozumieć swoje ograniczenia i nauczyć go rozpoznawania ich. Uczniowie nieśmiali często borykają się z destrukcyjnymi myślami typu: „nie poradzę sobie". Istotne jest, by w klasie dominowało podmiotowe (humanistyczne) podejście do każdego z uczniów, by ceniona była indywidualność i własne - nie zawsze podzielane przez większość - poglądy (Jagieła 2005; Zubrzycka-Maciąg, Wosik-Kawala 2012, s. 64-65).

W pracy z uczniem nieśmiałym należy zadbać o właściwą atmosferę w klasie, by dziecko czuło się w niej bezpiecznie, rozpoznawać i wzmacniać mocne strony osoby nieśmiałej, organizować zajęcia w mniejszych podgrupach, by dzieci nieśmiałe mogły modelować zachowania osób otwartych i towarzyskich (Carducci 2008).

Wśród zasad postępowania z uczniem nieśmiałym w szkole Grażyna Ledzińska (za: Paszkowska, Łobacz 2013, s. 186-187) wymienia:

- stwarzanie klimatu zaufania i bezpieczeństwa, obniżających poziom lęku i niepokoju; 
- częste stosowanie wzmocnień pozytywnych w formie zachęt i pochwał, zachęcających do podjęcia aktywności i korzystnie wpływających na samoocenę ucznia;

- stwarzanie sytuacji społecznych, które pozwolą uczniowi na gromadzenie drobnych doświadczeń i przeżycie prawdziwego sukcesu;

- aranżowanie dziecku sposobności do występowania przed innymi osobami (za jego zgodą), stopniowe oswajanie go z takimi sytuacjami;

- prowadzenie indywidualnych rozmów z uczniem nieśmiałym, które mają na celu korygowanie u niego myśli krytycznych i karzących na swój temat;

- uświadamianie uczniom nieśmiałym, że wchodzenie w kontakt $\mathrm{z}$ innymi ludźmi niesie ze sobą ryzyko odrzucenia;

- opracowanie i wprowadzenie Kodeksu Postępowania Nieśmiałych;

- podkreślanie wartości przyjaźni w przezwyciężaniu własnej nieśmiałości;

- uczenie dziecka dawania i przyjmowania od innych komplementów;

- dawanie uczniowi do zrozumienia, by w relacjach społecznych skupiał się na innych ludziach, co pomaga uczniowi przezwyciężać nawyk koncentracji na własnej osobie;

- zachęcanie dziecka do podejmowania z innymi kontaktów „twarzą w twarz” oraz podkreślanie walorów tej formy komunikacji;

- pomaganie uczniowi w przezwyciężaniu symptomów niepokoju poprzez proste ćwiczenia oddechowe.

Ogromną rolę w zapobieganiu nieśmiałości wśród dzieci i młodzieży pełnią osoby dorosłe - rodzice, nauczyciele, wychowawcy, gdyż mają znaczący wpływ na kształtowanie osobowości młodych osób. Uznając odrębność każdego z młodych ludzi, pomagamy im rozwijać poczucie własnej wartości, popieramy ich próby rozwijania się, zachęcamy ich do tego, by stali się kimś szczególnym. Osoby nieśmiałe powinny być obdarzone bezwarunkową miłością, aby mogły zaakceptować siebie, próbując jednocześnie stać się kimś więcej (Zimbardo 2007).

Wysiłek rodziców, nauczycieli, wychowawców włożony w wychowanie dziecka/ucznia/wychowanka sprzyja pozytywnemu przejściu poszczególnych faz rozwojowych i opanowaniu licznych kompetencji, co zwiększa szansę śmiałego, odważnego życia (Zabłocka 2012).

W oddziaływaniach wychowawczych skierowanych na osoby nieśmiałe warto wzmacniać ich niezależność, stwarzać warunki sprzyjające rozwojowi ich aktywności i samodzielności. W przypadku jednostek o dużym poziomie nieśmiałości ważną rolę może odegrać też wsparcie psychologiczne. W literaturze można znaleźć istotne wskazówki dotyczące sposobów i kierunków w zakresie profilaktyki i terapii nieśmiałości (Hammer 2000; Zabłocka 2008). 


\section{LITERATURA}

Borecka-Biernat D., 2000, Poziom samooceny a zachowania nieśmiałe młodzieży w sytuacji ekspozycji społecznej. W: R. Poprawy (red.), Psychologiczna analiza wybranych problemów funkcjonowania społecznego młodzieży. Wrocław, Wydawnictwo Uniwersytetu Wrocławskiego, 45-59.

Borecka-Biernat D., 2001, Zachowanie nieśmiałe młodzieży w trudnej sytuacji społecznej. Kraków, Impuls.

Carducci B., 2008, Nieśmiałość. Nowe odważne podejście. Kraków, Znak.

Dąbrowska T.E., Wojciechowska-Charlak B., Między praktyka a teoriq wychowania. Lublin, UMCS.

Dzwonkowska I., 2003, Nieśmiałość i jej korelaty. „Przegląd Psychologiczny”, t. 46, nr 3, 307-322.

Głuszak A., 2012, Pokonać nieśmiałość. „Życie Szkoły”, nr 1, 25-28.

Gromelska A., 2009, Nieśmiałość - jak uczyć dziecko pewności siebie?. „Życie Szkoły”, nr 7, 19-22.

Hammer H., 2000, Oswoić nieśmiałość. Warszawa, Veda.

Harwas-Napierała B., 1979, Nieśmiałość dziecka. Poznań, Wydawnictwo Naukowe UAM.

Harwas-Napierała B., 1995, Nieśmiałość dorosłych. Geneza - Diagnostyka - Terapia. Poznań, Wydawnictwo Fundacji Humaniora.

Jagieła J., 2005, Trudny uczeń w szkole. Krótki przewodnik psychologiczny. Kraków, Wydawnictwo RUBIKON.

Januszewska E., 2000, Nieśmiałość a poziom lęku u dzieci w młodszym wieku szkolnym. „Przegląd Psychologiczny”, t. 3, nr 4, 481-497.

Kowolik P., 2013, Dziecko trudne. „Nauczyciel i Szkoła” 2(54), 93-99.

Kwiatkowska G.E., Łukasik A., (red.) 2011, Jednostka w ponowoczesnym świecie. Lublin, Wydawnictwo UMCS.

Leary M., Kowalski R.M., 2001, Lęk społeczny. Gdańsk, Gdańskie Wydawnictwo Psychologiczne.

Łobocki M., 1989, Trudności wychowawcze w szkole. Lublin, Wydawnictwo UMCS.

Paszkiewicz A., Łobacz M., 2013, Uczeń o specjalnych potrzebach wychowawczych w klasie szkolnej. Warszawa, Dyfin.

Pilch T., (red.) 2007, Encyklopedia pedagogiczna XXI wieku. t. 6. Warszawa, Su-U., Wydawnictwo Akademickie ŻAK.

Rogers B., 2011, Trudna klasa. Opanować, wychować, nauczyć....Warszawa, Fraszka Edukacyjna.

Słownik Współczesnego Języka Polskiego, 1998, Warszawa, Wydawnictwo Reader's Digest Przegląd. 
Umecka M., 2008, Dziecko nieśmiałe w szkole. „Problemy opiekuńczo-wychowawcze”, nr 10, 22-27.

Zabłocka M., 2008, Przezwyciężanie nieśmiałości u dzieci. Warszawa, Wydawnictwo Naukowe Scholar.

Zabłocka M., 2012, Zrozumieć nieśmiałość. Aspekty diagnostyczne i terapeutyczne. Bydgoszcz, Wydawnictwo Uniwersytetu Kazimierza Wielkiego.

Zarzecki L., 2012, Teoretyczne podstawy wychowania. Teoria i praktyka w zarysie. Jelenia Góra, KPSW.

Zimbardo P.G., 2007, Nieśmiałość. Co to jest? Jak sobie z nią radzić?. Warszawa, Wydawnictwo Naukowe PWN.

Zubrzycka-Maciąg T., Wosik-Kawala D., 2012, Wychowanie w szkole. Wskazówki dla nauczycieli. Lublin, Wydawnictwo UMCS.

\title{
THE DIFFICULTIES FACED BY SHY STUDENTS
}

\begin{abstract}
This study concerns the issue of shy students. This problem and its consequences are often played down by school authorities, including teachers. The article focuses on showing shyness as one of the manifestations of educational difficulties. The concept of shyness has been defined and attention has been paid to the specifics of this phenomenon and the problems faced by shy students. A shy student is described as polite, tactful, and even worth imitating, meanwhile shyness can have a very negative impact on a young person's life. Therefore, it is necessary to sensitize teachers and educators to the needs of a shy student and the need to take special educational actions towards him/her.
\end{abstract}

Keywords: educational difficulties, difficult student, shyness, shy student 